\title{
The factor VIII protein and its function
}

\author{
Anna Mazurkiewicz-Pisarek ${ }^{1 凶}$, Grażyna Płucienniczak¹, Tomasz Ciach² and Andrzej \\ Płucienniczak ${ }^{1}$
}

IInstitute of Biotechnology and Antibiotics, Bioengineering Department, Warszawa, Poland; 2Warsaw University of Technology, Faculty of Chemical and Process Engineering, Department of Biotechnology and Bioprocessor Engineering, Warszawa, Poland

\begin{abstract}
Factor VIII (FVIII), an essential blood coagulation protein, is a key component of the fluid phase blood coagulation system. Human factor VIII is a single chain of about 300 $\mathrm{kDa}$ consisting of domains described as A1-A2-B-A3-C1C2. The protein undergoes processing prior to secretion into blood resulting in a heavy chain of $200 \mathrm{kDa}$ (A1-A2-B) and a light chain of $80 \mathrm{kDa}$ (A3-C1-C2) linked by metal ions. The role of factor VIII is to increase the catalytic efficiency of factor IXa in the activation of factor $X$. Variants of these factors lead frequently also to severe bleeding disorders.
\end{abstract}

Key words: Factor VIII (FVIII), molecular structure, function, hemophilia A, bleeding disorders

Received: 11 May, 2015; revised: 22 September, 2015; accepted: 13 January, 2016; available on-line: 28 January, 2016

\section{INTRODUCTION}

Coagulation factor VIII (anti-hemophilic factor A) is a glycoprotein synthesized mainly in hepatocytes, but also in kidneys, endothelial cells and lymphatic tissue. It is one of the largest coagulation factors (2332 amino acids, molecular weight of $293 \mathrm{kDa}$ ) present in the bloodstream in association with von Willebrand factor (vWF) in a non-covalent complex (Vehar et al., 1984; Gitschier et al., 1984; Toole et al., 1984). The vWF protects factor VIII from premature proteolysis and transfers it to sites of endothelial injury. The half-life of coagulation factor VIII is about 12 hours. The active form of factor VIII (FVIIIa) is a non-enzymatic cofactor for the prothrombinase and tenase complex in the intrinsic coagulation pathway that accelerates factor $\mathrm{X}$ activation induced by activated factor IX (FIXa) in the presence of phospholipids and calcium ions.

The gene for factor VIII is located on the X chromosome (Xq28). A mutation in this gene that codes for coagulation factor VIII results in congenital bleeding disorder, i.e. hemophilia A. This mutation almost exclusively occurs in male germ cells. The effect of the mutation is absent or decreased synthesis of factor VIII or synthesis of abnormal protein (Thompson et al., 2003; Hong et al., 2007).

Hemophilia A is diagnosed in 1 of 5000 male newborns. In Poland, frequency of hemophilia is estimated at $1: 12300$ inhabitants. In approximately $30-50 \%$ of affected patients mutation occurs spontaneously and their family history is negative.

Treatment of bleedings in course of hemophilia and related disorders consists of supplementation of missing coagulation factor i.e. its substitution (Windyga et al., 2004).

\section{HISTORICAL OVERVIEW}

The first lyophilized factor VIII concentrates appeared on the market in the late 1960s and since that time they have been the basis of hemophilia A treatment. Unfortunately, quite quickly, substitutive therapy was found to be also associated with some very serious side effects for patients. The concentrates produced from pooled plasma received from thousands of donors were sources of hepatitis B virus, and since 1989 also of hepatitis C virus. In the early 1980 s, in a very short time, $60-80 \%$ of hemophilia patients became infected by human immunodeficiency virus (HIV) that was contained in lyophilized concentrates.

Another breakthrough in hemophilia treatment started with the discovery of human factor IX and factor VIII genes in 1982 and 1984, respectively (Lusher et al., 1993). Soon after these discoveries some research groups proved that mammalian cells transfected with human factor VIII cDNA were able to synthesize that factor. Recombinant factor VIII manufactured using genetic engineering technology became available in the early 1990s (Bray et al., 1994).

In the 1990s, when recombinant factor VIII became available for patients, it was predicted to replace human plasma derived concentrates. Unfortunately, at present only in some countries, for example Canada and Ireland, $100 \%$ of affected patients receive recombinant factor VIII. In The United States that percentage is about 65\% and in many rich and highly developed countries of the European Union this ratio is significantly lower.

In Poland, only coagulation factor concentrates manufactured from human plasma are used. The reason for that is very high production cost of recombinant factor VIII (Chen et al., 1995; Windyga, 2004).

So far, all available recombinant factor VIII formulations have been produced in mammalian cells: Chinese hamster ovarian cells (CHO) and baby hamster kidney cells (BHK) (Lucas et al., 1996; Fussengger et al., 1999).

\section{BIOCHEMICAL CHARACTERIZATION OF COAGULATION FACTOR VIII}

Human coagulation factor VIII is a glycoprotein encoded by a gen of 186000 base-pairs (bp) comprising 26 exons. It is synthesized as a single polypeptide chain containing 19 signaling peptides. A singularity of the fac-

-

Abbreviations: BHK, baby hamster kidney; $\mathrm{CHO}$, Chinese hamster ovarian cells; APC, activated protein C; HBV, hepatitis B virus; HCV, hepatitis B virus; HIV, human immunodeficiency virus. 


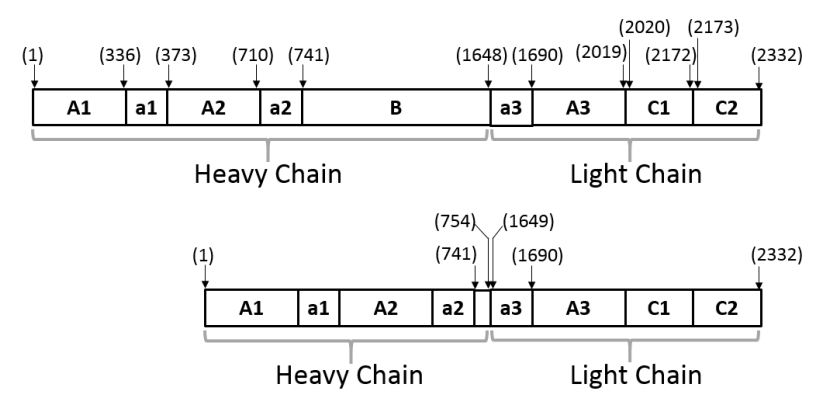

Figure 1. Schematic of two different forms of coagulation factor VIII - the diagram showing domain organization in full-length and $B$ domain-deleted forms of coagulation factor VIII (Ngo et al., 2008). A1, A2, B, A3, C1, C2 are domains forming coagulation factor VIII.

tor VIII gene is the presence of two additional genes known as F8A and F8B genes in its intron 22 (IVS22). F8A is transcribed in the opposite direction to the factor VIII gene. There are two additional copies of F8A outside the factor VIII gene located at $400 \mathrm{kbp}$ towards the telomere. So far, F8A and F8B functions are not known.

Factor VIII consists of 2332 amino acids forming six domains described as A1-A2-B-A3-C1-C2 (Kurachi \& Davie, 1982). In the blood, under the influence of proteolytic processes (furin protease), this protein is divided into two chains: a heavy chain of $200 \mathrm{kDa}$ (A1-A2-B) and a light chain of $80 \mathrm{kDa}$ (A3-C1-C2). The chains are interconnected by a covalent bound. Limited proteolysis of the B chain results in heterogeneous population of active factor VIII forms of varied molecular weights, ranging from $90 \mathrm{kDa}$ to $200 \mathrm{kDa}$. The smallest of generated heavy chain forms $(90 \mathrm{kDa})$ together with the light chain $(80 \mathrm{kDa})$ form the active form of the coagulation factor VIII. The resulting active form of FVIII contains glycosylated sites-free domain B, i.e. amino acids Arg740 to Glu1649. Ser743 in the N-terminal region of domain $\mathrm{B}$ is connected with Glu1638 in the C-terminal of domain B forming a SQ specific site comprising 14 amino acids (SFSQNPPVLKRHQR) situated between domains A2 and A3 (Fig. 1). The presence of this site allows intracellular cleavage of the $170 \mathrm{kDa}$ single chain and formation of the $80-90 \mathrm{kDa}$ active complex. It is correlated with the presence of amino acids in positions -1 and -4 (relative to the Glu1649 site) in SQ enabling proteolytic cleavage by furin protease. Factor VIII is inactive or minimally active as a cofactor in blood coagulation process. Its activation as a cofactor occurs only after proteolytic cleavage in SQ site (Thompson et al., 2003; Ngo et al., 2008).

\section{A domains}

A domains of coagulation factor VIII are homologous to the ones of coagulation factor $\mathrm{V}(\mathrm{FV})$ and ceruloplasmin. There are three A domains within FVIII structure - A1, A2 and A3. The A1 domain comprises 336 amino acids, the A2 domain - 337 amino acids and the A3 domain - 329 amino acids. Each domain was found to contain two highly conserved suprasecondary structures, the so-called $\beta$-barrels. They are concentric and bend towards each other. The second subdomain interacts with the first subdomain of the following domain. Disulphide bonds are located along the "bottom" protein surface (McMullen et al., 1995). Both A1 and A3 domains contain single copper atom (Tagliavacca et al., 1997). The main antibody epitope is present in the A2 domain in amino acid
484-508 sites, while another one is placed between amino acids 558 and 565 affects FIXa and it is likely to be the main catalyst of cofactor and enzyme reaction activation (Fay et al., 1994; Healey et al., 1995; O’Brein et al., 1995; Bajaj et al., 2001). The A2 domain is the one which can be dissociated the most easily in the active form of factor VIII (FVIIIa). The peptide sequence of the A2 domain terminal (amino acids 1810 to 1818) forms specific FIXabinding site (Lenting et al., 1996). A specific FX-binding site is located at the A1 domain terminal (amino acids 337 to 372) (Lapan \& Fay, 1997). In the Arg336 site of the A1 domain and the Arg562 site of the A2 domain there is a binding site for active protein C (APC), an inhibitor of coagulation process (Fay, 2004; Nogami et al., 2005).

\section{B domain}

The function of the B domain, comprising $40 \%$ of FVIII mass, is not fully understood. This domain does not affect factor VIII activity in the process of blood coagulation. B domain-deleted natural or recombinant FVIII heterodimers show comparable or even higher activity. The central B domain is the largest of all the domains and is highly glycosylated (Pittman et al., 1993; Berntorp, 1997).

\section{C domains}

There are two $\mathrm{C}$ domains within the FVIII structure - C1 and C2. The C1 and C2 domain comprise 153 and 160 amino acids, respectively. Crystal structure of the $\mathrm{C} 2$ domain consists of $\beta$-sandwich forming the internal domain structure, and attached $\beta$-hairpins and loops forming a hydrophobic surface. On the top of the first $\beta$-hairpin structure are amino acids Met2199 and Phe2200. These are two hydrophobic amino acids attached to adjacent loops. They indicate the middle of the C2 domain surface responsible for phospholipid linkage to coagulation factor VIII. On the opposite C2 domain side there is a $\mathrm{C} 1$ and $\mathrm{A} 1$ domain binding site. The $\mathrm{C}$ domains are interconnected in amino acids 2168-2175 sites through Met2176 and Thr2023 as well as amino acid Val2294s and Ser2029 interactions. The C2 and A1 domains connect through amino acids Arg121 and Leu2302. The C2 domain also contains thrombin and active factor $\mathrm{Xa}$ form binding sites. Although the $\mathrm{C} 1$ domain plays no specific role in coagulation factor VIII, research performed so far has suggested that it has an impact on von Willebrand factor and C2 domain linkage strengthening (Pratt et al., 1999; Liu et al., 2000). Threedimensional structure of B domain-deleted factor VIII is shown in Fig. 2.

\section{COAGULATION FACTOR VIII ACTIVATION}

Coagulation factor VIII is proteolytically activated by thrombin. Activation results from cleavage of the heavy chain in: Arg372 (A1 — A2 domain linkage) and Arg740 (A2 - B domain linkage) amino acid sites and cleavage of the light chain in amino acid site Arg1689 (B - A3 domain linkage). The active form of coagulation factor VIII, FVIIIa is a trimer consisting of A1 (amino acids 1-372), A2 (amino acids 373-740) and linked A3 - C1-C2 (amino acids 1690-2332) domains. The B domain does not comprise the active coagulation factor VIII form. The function of FVIIIa in the coagulation cascade is to accelerate FX activation in the presence of FIXa, phospholipids and calcium ions (Eaton \& Vehar, 1986; Bhopale \& Nanda, 2003; Fay, 2004). 


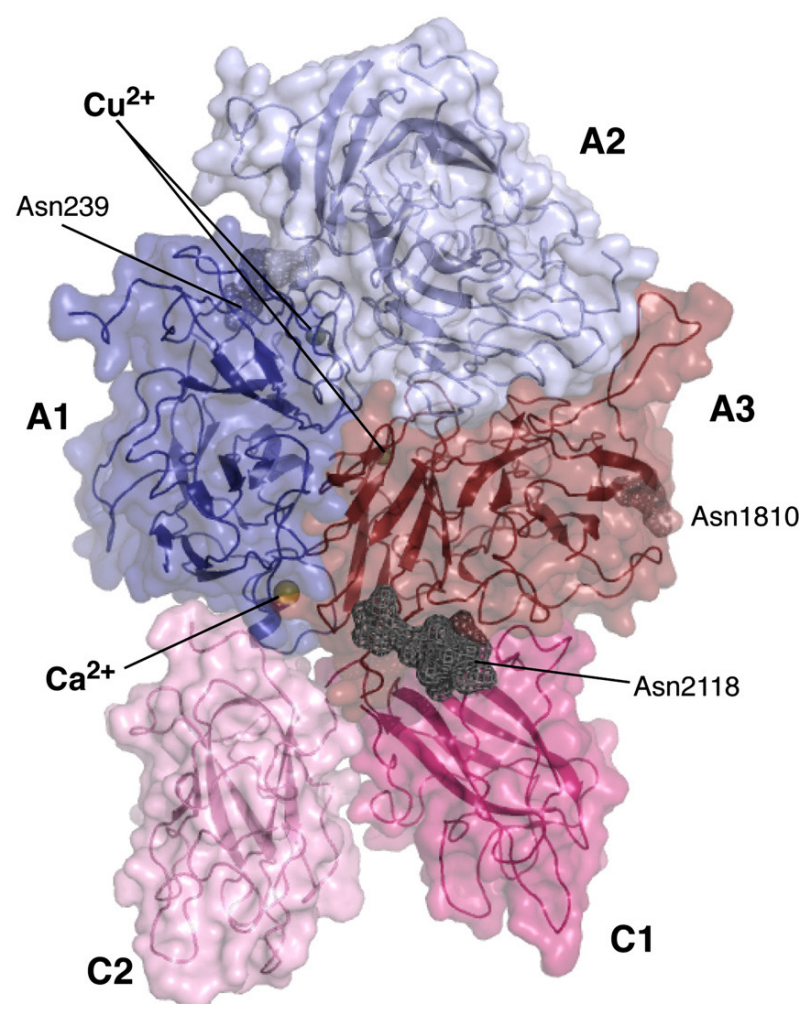

Figure 2. Three-dimensional structure of B domain-deleted coagulation factor VIII (Ngo et al., 2008, by permission). A1, A2, B, A3, C1, C2 are domains forming coagulation factor VIII.

Following thrombin-induced factor VIII activation, FVIIIa binds to the phospholipid surface and starts to impact on FIXa. FVIIIa accelerates FX activation about $10^{5}$ times.

Inactivation of the FVIIIa is the result of the cleavage of the A1 and A2 domains in specific Arg336 and Arg562 sites by the active C protein (APC) (Waaler, 1957; Tool et al., 1986; Myles et al., 2002).

The process of coagulation factor VIII activation is shown in Fig. 3.

Because of differences in phospholipid binding between the native and the recombinant $\mathrm{B}$ domaindeleted factor VIII, plasma activity of factor VIII in hemophilia patients receiving the recombinant product should be determined using a chromogenic method, not the commonly used one-step coagulation method. The chromogenic method comprises two steps: factor VIII-dependent factor X activation in a complex consisting of purified constituents and enzymatic cleavage of chromogenic substrate by factor $\mathrm{Xa}$ with release of a colouring compound (chromophore), the amount of which can be measured by spectrophotometric method (Mikaelsson et al., 2001).
Factor VIII

\begin{tabular}{|c|c|c|c|c|c|c|c|c|}
\hline A1 & a1 & A2 & a2 & B & a3 & A3 & C1 & C2 \\
\hline
\end{tabular}

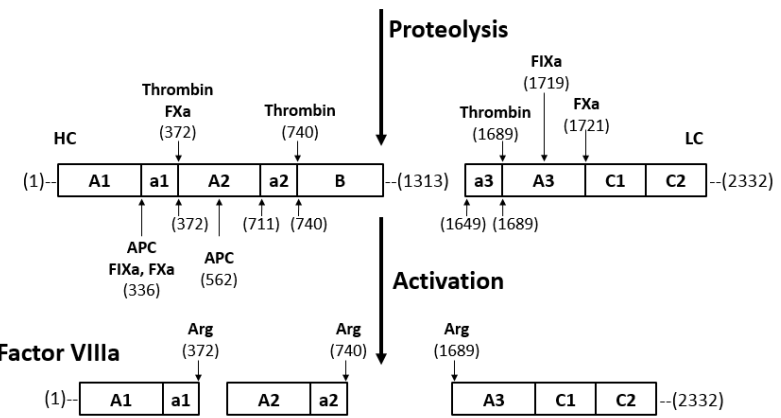

Figure 3. Schematic of coagulation factor VIII activation to active form VIIla - the figure shows specific cleavage sites recognized by thrombin during activation process, FIXa and FXabinding sites and FVIII activation inhibitor, active protein $C$ (APC)-binding sites (Myles et al., 2002).

FVIII - coagulation factor VIII, FVIIIla - active form of coagulation factor VIII, FIXa - active form of coagulation factor IX.

\section{HEMOPHILIA A}

Hemophilia A is a congenital bleeding disorder caused by decreased activity of plasma coagulation factor VIII as a result of mutations present within the gene encoding this protein.

The most common mutation in patients with a severe form of hemophilia A (about $45 \%$ cases) is large inversion with translocation of exons 1-22 (including introns) as a consequence of homologous recombination between the F8A gene in intron 22 and one of the F8A copies present outside the coagulation factor VIII gene. This mutation occurs almost exclusively in male germ cells. Other mutations causing hemophilia are point mutations (85\% missense mutations and $15 \%$ nonsense mutations), $5 \%$ of which are large or small deletions and insertions as well as inversion within intron 1. Gene mutations result in absent or decreased factor VIII synthesis or abnormal protein expression (Lakich et al., 1993; Rossiter et al., 1994; Bagnally et al., 2002).

Similarly to all sex-linked gene dependent diseases, hemophilia A occurs mainly in men while women transmitting the disease are disease carriers. As within a specific family the transmitted gene carries the same mutation, men affected by the disease within one family have the same form of hemophilia. Daughters of men with hemophilia, mothers of at least two affected sons and mothers of one affected son in a family where one other relative has hemophilia are considered $100 \%$ disease carriers. Daughters of hemophilia carriers (including affected mens' sisters) and mothers of one affected son in a family where no other relation had the disease are likely to be hemophilia carriers. Probability of transmitting a de-

Table 1. Three forms of hemophilia - the table shows three possible forms of hemophilia with the related level of coagulation factor VIII activity expressed in International Units (IU) and the main symptoms of the disease.

\begin{tabular}{lll}
\hline $\begin{array}{l}\text { FVIII activity } \\
\text { IU/ml }\end{array}$ & $\begin{array}{l}\text { A form of } \\
\text { hemophilia }\end{array}$ & Main symptoms \\
\hline $\begin{array}{l}<0.01 \\
(<1 \% \text { normal range })\end{array}$ & Severe & $\begin{array}{l}\text { Spontaneous join and muscle bleedings; excessive bleedings after trauma, accidents, tooth } \\
\text { extractions, surgeries }\end{array}$ \\
$\begin{array}{l}0.01-0.05 \\
(1-5 \% \text { normal range) }\end{array}$ & Moderate & $\begin{array}{l}\text { Joint and muscle bleedings following mild trauma; excessive bleedings after trauma, acci- } \\
\text { dents, tooth extractions, surgeries }\end{array}$ \\
$\begin{array}{l}>0.05-<0.50 \\
(>5-50 \% \text { normal range) }\end{array}$ & Mild & Excessive bleedings after trauma, accidents, tooth extractions, surgeries \\
\hline
\end{tabular}


fective gene to a child by a disease carrier is 0.5 ; that means that the risk of hemophilia for a son and the risk of a daughter to become a disease carrier is $50 \%$. Because plasma factor VIII activity of carriers is usually about $50 \%$ of the normal range and it is sufficient for proper functioning of secondary haemostasis, the carriers rarely present with excessive bleedings tendency (Plug et al., 2006).

Hemophilia bleedings result from secondary haemostasis insufficiency. The primary haemostasis, i.e. platelet adhesion, activation and aggregation is normal. However, the haemostatic plug made of platelets is not sufficiently strengthened by fibrin as due to factor VIII deficiency an amount of thrombin sufficient for transforming fibrinogen into fibrin is not produced. Clots with a weak structure easily disintegrate what manifests as an excessive bleeding tendency. Bleeding intensity depends on the level of factor VIII deficiency. There are three forms of hemophilia: severe, moderate and mild (Table 1). Determination of hemophilia form is based on deficient plasma coagulation factor activity. The activity is expressed in International Units (IU). It is assumed that 1 IU reflects a coagulation factor activity in $1 \mathrm{~mL}$ of normal fresh plasma obtained from 9:1 blood to $3.2 \%$ sodium citrate mixture. Sample factor VIII activity is determined by comparison of its amount necessary to achieve a determined rate of factor $\mathrm{Xa}$ formation in the investigated mixture containing substances participating in factor $\mathrm{X}$ activation with the amount of International Standard needed to achieve the same rate of factor $\mathrm{Xa}$ production (Bolton-Maggs \& Pasi, 2003, Windyga, 2003).

The basis of hemophilia treatment is the increase of blood activity of deficient coagulation factor in order to inhibit or prevent an active bleeding. Therapeutics used in hemophilia treatment and prevention include:

- Human plasma derived lyophilized factor VIII concentrates (plasma-derived concentrates);

- Recombinant coagulation factors produced by genetic engineering technology. These concentrates are produced by mammalian cells transfected with coagulation factor VIII gene (Table 2);

- 1-desamino-8-D-arginine vasopressin (DDAVP), called desmopressin (antidiuretic hormone derivate);
- Additional therapeutics such as antifibrinolytic and local haemostatic agents (Windyga et al., 2008).

Development of the anti-factor (F)VIII antibodies was one of the main difficulties in treatment of patients with haemophilia A over the last 2 decades. Numerous studies have been dedicated to understanding the mechanism leading to development of inhibitory anti-factor (F)VIII antibodies. They revealed that there are multiple decisive factors for the immune response that involve components of both constitutional and therapy-related nature (Astermark, 2015). If an inhibitor has previously been identified within the family, the higher risk for siblings to develop an inhibitor is observed (Gill, 1999; Astermark et al., 2001). Additionaly, recent preliminary findings also suggest that the epitopes of these antibodies may be inherited and shared constitutionally within families. This results may have potential therapeutic implications (Konigs, personal communication*).

As a result, the latest efforts are focused on modifying the factor FVIII concentrates to enhance some aspects of their biology, most notably their half-life, functional activity and immunogenicity (Laffan, 2015).

\section{RECOMBINANT BLOOD COAGULATION FACTORS}

There are three generations of pharmaceuticals containing recombinant coagulation factor VIII. The first generation includes a recombinant factor VIII which in aspect of biochemical and pharmacokinetic properties does not significantly differ from the native factor VIII. So far no single case of HBV, HCV or HIV infection related to the use of these formulations has been reported. However, risk of infectious virus particle transmission related to the first generation concentrates usage has not been fully eliminated. Human and animal proteins enriching culture media and human albumin acting as a terminal product stabilizer are still potential sources of infection. In the second generation concentrates human albumin was replaced by carbohydrate compounds which play the role of a stabilizer. As culture media contain human proteins, which can theoretically be a source of infection, the second generation concentrates undergo an additional viral inactivation procedure. Among the

Table 2. Recombinant coagulation factor VIII concentrates (Windyga, 2004) - the table presents commercially available recombinant coagulation factors VIII. They are produced by genetic engineering technology by mammalian cells transfected with coagulation factor VIII gene.

\begin{tabular}{llllll}
\hline Name & Factor & Transfected Cells & Culture Medium Proteins & Virus Inactivation Procedure & Generation \\
\hline $\begin{array}{l}\text { Recombinate } \\
\text { (Baxter BioScience) }\end{array}$ & VIII & CHO & $\begin{array}{l}\text { Bovine albumin, insulin, } \\
\text { aprotinin }\end{array}$ & NO & 1 \\
\hdashline $\begin{array}{l}\text { Kogenate* } \\
\text { (Bayer) }\end{array}$ & VIII & BHK & Human albumin & NO & 1 \\
\hdashline $\begin{array}{l}\text { Helixate* } \\
\text { (Aventis Behring) }\end{array}$ & VIII & BHK & Human albumin & NO & 1 \\
\hdashline $\begin{array}{l}\text { ReFacto(BDDr) } \\
\text { (Wyeth/Genetic Inst.) }\end{array}$ & rVIII & CHO & Human albumin & S/D & 2 \\
\hline $\begin{array}{l}\text { Kogenate } \\
\text { (Bayer) }\end{array}$ & VIII & BHK & Human albumin & S/D & 2 \\
\hdashline $\begin{array}{l}\text { Helixate } \\
\text { (Avensis Behring) }\end{array}$ & VIII & BHK & Human albumin & S/D & 2 \\
\hline $\begin{array}{l}\text { Advate rAHF } \\
\begin{array}{l}\text { (Baxter BioScience) } \\
\hline\end{array}\end{array}$ & rVIII & CHO & No & S/D & 3 \\
\hline
\end{tabular}

*Production was stopped; CHO, Chinese hamster ovarian cells; BHK, baby hamster kidney cells; S/D, organic solvent/detergent 
second generation concentrates of special interest is $B$ domain-deleted factor VIII. The B domain-deleted factor VIII mRNA expression in CHO cells is 20 times higher than the native factor VIII mRNA expression. So far, only one of the third generation products has been registered. The culture medium is not enriched by human or animal proteins, and carbohydrates are used as the stabilizer, instead of human albumin. Mouse monoclonal antibodies that can be a potential source of viruses are used in the purification process. Work on the new product generation is ongoing; in the purification process mouse monoclonal antibodies are to be replaced by chemically synthesized ligands (Bihoreaue et al., 1991; Sandberg et al., 2001; Saenko et al.; 2003; Mannucci, 2010).

Production of B domain-deleted factor VIII is an example of how genetic engineering may "upgrade nature".

The third generation of recombinant coagulation factor VIII has provided concentrates for haemophilia treatment which practically eliminated risk of infectious virus particle transmission. The latest step in the production of conventional FVIII molecules involves the introduction of rFVIII manufactured in a human cell line. This approach has some theoretical advantages that have been realised in practice. These include more complete post-translational modifications such as tyrosine sulphation, resulting in improved binding to VWF and a consequential modest increase in half-life. It also

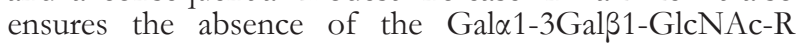
(alpha-Gal) and N-glycolylneuraminic acid sugar structures in the factor FVIII which, in some circumstances, have proved to be immunogenic (Sandberg et al., 2012, Kannicht et al., 2013). It is not yet known whether this change will reduce the development of anti-FVIII antibodies in humans. A single chain FVIII molecule also has an improved affinity for VWF (Zollner et al., 2014). Whilst these options represent new treatments, they are not qualitative leaps in therapy.

\section{CONCLUSIONS}

Coagulation factor VIII is a protein involved in the blood coagulation process. Its absence or low blood activity causes haemophilia A. The treatment of haemophilia-related bleedings and related bleeding disorders consists of coagulation factor VIII substitution. Nowadays few types of substitutes are used worldwide. The most commonly used therapeutics are plasma-derived products. Even though no patient infections have been observed lately, it cannot be excluded that they are completely free of any infectious particles. The latest researche is directed at development of coagulation factor that can effectively overcome immunological response or has increased half-time but it is still not free from viral transmission risk.

The next step in haemophilia treatment development would be obtaining recombinant coagulation factor VIII by less expensive prokaryotic expression system. That would allow significant lowering of production costs, shortening of production time, better product availability, and - first of all — elimination of the risk of infection.

\section{REFERENCES}

Astermark J, Berntorp E, White GC, Kroner BL (2001) MIBS: further support for genetic predisposition to inhibitor development in haemophilia patients. Haemophilia 7: 267-272. doi: 10.1182/ blood-2014-08-535328.
Astermark J (2015) FVIII inhibitors: pathogenesis and avoidance. Blood 125: 2045-2051.

Bagnally RD, Veasemm N, Green PM, Gianelli F (2002) Reccurent inversion bracking intron 1 of the factor VIII gen eis a frequent cause of severe heamophilia A. Blood 99: 168-174.

Bajaj SP, Schmidt AE, Mathur A, Padmanabhan K, Zhong D, Mastri M (2001) Factor IXa: Factor VIIIa interaction - helix 330-338 of factor IX interacts with residues 558-565 and spatially adjacent regions of the A2 subunit of factor VIIIa. J Biol Chem 276: 1630216309.

Berntorp E (1997) Second generation, B-domain deleted recombinant factor VIII. Thrombosis and Haemostasis 78: 256-260.

Bhopale GM, Nanda RK (2003) Blood coagulation factor VIII: An overview. I Biosci 28. strony?

Bihoreau N, Paolantonacci P, Bardelle C, Fontaine-Aupart MP, Krishnan S, Yon J, Romet-Lemonne JP (1991) Structural and functional characterization of factor VIII-delta II, a new recombinant factor VIII lacking most of the B-domain. Biochem J 277: 23-31.

Bolton-Maggs PHB, Pasi JK (2003) Heamophilias A and B. Lancet 361: 1801-1809.

Bray GL, Gomperts ED, Courter S, Gruppo R, Gordon EM (1994) A multicenter study of recombinant factor VIII: safety, efficiency and inhibitor risk in previously untreated patients with haemophilia A. Blood 83: 2428-2435.

Chen C, Fang XD, Zhu J, Wu XF, Zhang ZC, Gu JX, Wang ZY, Chi CW (1995) The gene expression of coagulation factor VIII in mammalian cell lines. Thromb Res 95: 105-115.

Eaton DL, Vehar GA (1986) Factor VIII structure and proteolytic processing. Prog Haemostasis Thromb 8: 47-70.

Fay PJ, Beattie T, Huggins CF, Regan LM (1994) Factor FVIIIa A2 subunit residues 558-565 represent a factor IXa interactive site. J Biol Chem 29: 20522-20527.

Fay JP (2004) Activation of factor VIII and mechanisms of cofactor action. Blood Reviews 18: 1-15.

Fussengger M, Bailey JE, Hauser H, Mueller PP (1999) Genetic optimization of recombinant glycoprotein production by mammalian cells. Trends Biotechn 17: 35-42.

Gill JC (1999) The role of genetics in inhibitor formation. Thromb Haemost.82(2): 500-504.

Gitschier J, Wood IW, Goralka TM, Wion KL, Chen EY, Eaton DH, Lehar GA, Capon DJ, Lawn RM (1984) Characterization of the human factor VIII gene. Nature 312. strony?

Healey JF, Lubin IM, Nakai H, Saenko EL, Hoyer LW, Scandella D (1995) Residues 484-508 contain a major determinant of the inhibitory epitope in the A2 domain of human factor VIII. J Biol Chem 270: 14505-14509.

Hong F, Leming W, Hongbao W (2007) The protein structure and effect of factor VIII. Thrombosis Res 119: 1-13.

Kannicht C, Ramstrom M, Kohla G, Tiemeyer M, Casademunt E, Walter O, Sandberg H (2013) Characterisation of the post-translational modifications of a novel, human cell line-derived recombinant human factor VIII. Thrombosis Res 131: 78-88. doi: 10.1016/j.thromres.2012.09.011.

Kurachi K, Davie EW (1982) Isolation and characterization of a cDNA coding for human factor IX. Proc Natl Acad Sci 79: 6461-6464.

Laffan M (2015) New products for the treatment of haemophilia. Brit J Haematol. doi: 10.111/bjh.13797.

Lakich D, Kazazjan HH, Antonarakis SE, Gitscher J (1993) Inversions disrupting the factor VIII gene are a common cause of severe heamophilia A. Natl Genet 5: 236-241.

Lapan KA, Fay PJ (1997) Localization of a factor X interactive site in the A1 subunit of factor VIIIa. J Biol Chem 272: 2082-2088.

Lenting PJ, van de loo JW, Donath MJ, van Mourig JA, Mertens K (1996) The sequence Glu1811-Lys1818 of human blood coagulation factor VIII comprises a binding site for activated factor VIII comprises a binding site for activated factor IX. J Biol Chem 271: 1935-1940.

Liu ML, Shen BW, Nakaya S, Pratt KP, Fujikawa K, Davie EW (2000) Hemophilic factor VIII C1- and C2-domain missense mutations and their modeling to the 1.5-angstrom human C2-domain crystal structure. Blood 96: 979-987.

Lucas KB, Giere LM, DeMarco RA, Shen A, Chisholm V and Crowley CW (1996) High-level production of recombinant proteins in $\mathrm{CHO}$ cells using a dicistronic DHFR intron expression vector. Nucleic Acids Res 24: 1774-1779.

Lusher JM, Arkin S, Abildgaard CF, Schwarz RS (1993) Recombinant factor VIII for the treatment of previously untreated patients with hemophilia A. N Engl Journal Med 328: 453-459.

Mannucci PM (2010) The safety and efficacy history of B-domainless factor VIII. Journal Coagulation Disorder, vol 2, issue 2, p 1.

McMullen BA, Fujikawa K, Davie EW, Hedner U, Ezban M (1995) Location of disulfide bonds and free cysteines in the heavy and light chains of recombinant human factor VIII (anti-hemophilic factor). Protein Sci 4: 4740-4746. 
Mikaelsson M, Oswaldsson U, Jankowski MA (2001) Measurement of factor VIII activity of B-domain deleted recombinant factor VIII. Seminars in Hematology 38: 13-23.

Myles T, Yun TH, Leung LL (2002) Structural requirements for the activation of human factor VIII by thrombin. Blood 100: 2820.

Ngo J Chi Ki, Huang M, Roth DA, Furie BC, Furie B (2008) Crystal structure of human factor VIII: implications for the formation of the factor IXa-factor VIIIa complex. Cell Press, Structure 16: 597-606. doi: $10.1016 /$ j.str.2008.03.001.

Nogami K, Zhou Q, Myles T, Leung LL, Wakabayashi H, Fay PJ (2005) Exosite-interactive regions in the A1 and A2 domains of factor VIII facilitate thrombin-catalyzed cleavage of heavy chain. J Biol Chem 280: 18476-18487.

O’Brien LM, Mastri M, Fay PJ (2000) Regulation of factor VIIIa by human activated protein $\mathrm{C}$ and protein $\mathrm{S}$ : inactivation of cofactor in the intrinsic factor Xase. Blood Rev 95: 1714-1720.

O'Brein LM, Medved LV, Fay PJ (1995) Localization of IXa and factor interactive sites. J Biol Chem 270: 27087-27092.

Pittman DD, Alderman E, Tomkinson KN, Wang JH, Giles AR, Kaufman RJ (1993) Biochemical, immunological, and in vivo functional characterization of B-domain deleted factor VIII. Blood 81: 2925-2935.

Plug I, Mauser-Bunschoten Indyga P, Brocker-Vriends AHJT (2006) Bleeding in carrierse of hemophilia. Blood 108: 52-56.

Pratt KP, Shen BW, Takeshima K, Davie EW, Fujikawa K, Stoddard BL (1999) Structure of the C2 domain of human factor VIII at 1.5 A resolution. Nature 402: 439-442.

Rossiter JP, Young N, Kimberland ML (1994) Factor VIII gene inversions causing severe heamophilia A originate almost exclusivelly in male germ cells. Human Mol Genet 3: 135-139.

Saenko EL, Ananyeva NM, Shima M, Hauser CAE, Pipes SW (2003) The future of recombinant coagulation factor. J Thromb Haemostasis 1: $922-930$.

Sandberg H, Almstedt A, Brandt J, Gray E, Holmquist L, Oswaldsson U, Sebring S, Mikaelsson M (2001) Structural and functional characteristics of the B-domain-deleted recombinant factor VIII protein, r-VIII SQ. Thrombosis Haemostasis 85: 93-100.

Sandberg H, Kannicht C, Stenlund P, Dadaian M, Oswaldsson U, Cordula C., Walter O (2012) Functional characteristics of the novel, hu- man-derived recombinant FVIII protein product, human-cl rhFVIII. Thrombosis Res 130: 808-817. doi: 10.1016/j.thromres.2012.08.311. Tagliavacca L, Moon N, Dunham WR, Kaufman RJ (1997) Identification and functional requirement of $\mathrm{Cu}(\mathrm{I})$ and its ligands within coagulation factor VIII. J Biol Chem 272: 27428-27434.

Thompson AR (2003) Structure and function of the factor VIII gene and protein. Seminars in Thrombosis and Hemostasis 29: 11-21.

Toole JJ, Knopf JL, Wozney JM, Sultzman LA, Becker JL, Pittman DD, Kauffman RJ, Brown E (1984) Molecular cloning of a cDNA encoding human antiheamophilic factor. Nature 312: 342-347.

Toole JT, Pittman DB, Orr EC, Murtha P, Wasley LC, Kaufman RJ (1986) A large region of human factor VIII is dispensable for in vitro procoagulant activity. Proc Natl Acad Sci 83: 5939-5942.

Vehar GA, Keyt B, Eaton D, Rodriguez H, O'Brien DP, Rotblat F, Oppermann H, Keck R, Wood WI, Harkins RN, Tuddenham EGD, Lawn RM and Capon DJ (1984) Structure of human factor VIII. Nature 312: 337-342.

Waaler BA (1957) Simultaneous contribution to the formation of thrombin by the intrinsic and extrinsic blood clotting systems. Scandinav J Clin Lab Invest 9: 322-330.

Windyga J (2004) Recombinant coagulation factorts. Acta Haematologica Polonica 35: 1-10.

Windyga J, Chojnowski K, Klukowska A, Lętowska M, Mital A, Podolak-Dawidziak M, Zdziarska J, Zawilska K (2008) Treatment procedures in heamophilias A and B. Acta Haematol Pol 39: 537-564 (in Polish).

Windyga J, Łopaciuk S, Stefańska E (2004) Hemophilia and other inherited blood coagulation disorders in Poland. Polskie Archiwum Medycyny Wewnetrznej 112: 1197-1202 (in Polish).

Windyga J (2003) Diagnostyka laboratoryjna zaburzeń hemostazy. Laboratory diagnostics of hemostasis disorders. Manual for medical studies. PZWL 192-225 (in Polish).

Zollner S, Raquet E, Claar P, Muller-Cohrs J, Metzner HJ, Weimer T, Pragst I, Dickneite G, Schulte S (2014) Non-clinical pharmacokinnetics and pharmacodynamics of rVIII-SingleChain, a novel recombinant single-chain factor VIII. Thrombosis Res 134: 125-131. doi: 10.1016/j.thromres.2014.03.028. 